\title{
Cocoa Production as Affected by Shade Tree Species and Soil Quality
}

\author{
Tria Yulianti ${ }^{1)}$, Soetanto Abdoellah'²), Didik Suprayogo(1), and Niken Puspita Sari ${ }^{2 /}$ \\ ${ }^{1)}$ Soil Department, Faculty of Agriculture, Brawijaya University, Malang, Indonesia \\ ${ }^{2)}$ Indonesian Coffee and Cocoa Research Institute, Jl. P.B. Sudirman 90, Jember, Indonesia \\ ${ }^{*}$ Corresponding author: stanto@iccri.net \\ Received: 13 March 2018 / Accepted: 2 May 2018
}

\begin{abstract}
Cocoa is one of the agricultural commodities that have important role and are reliable in realizing agricultural development program of Indonesia. The cocoa production of Indonesia tends to decrease that caused by in appropriate farming. This research aimed to evaluate the shade management to cocoa productivity and evaluating the correlation between soil quality and the cocoa production with the different shade management. This research was conducted from October 2016 until June 2017 in Kaliwining Experimental Station and Soil Laboratory of Indonesian Coffee and Cocoa Research Institute (ICCRI), Jember, Indonesia. Clones at the trial plots were Sulawesi 1 and Sulawesi 2, 10 years old, and arranged in $3 \mathrm{~m} \mathrm{x} 3 \mathrm{~m}$ spacing. The design of this research was conducted by observing parameters of sample trees on cocoa field. This research used three observation plots, with shade trees of leucaena (Leucaena sp.), teak (Tectona grandis), and teak combined with krete (Cassia surithensis) shade. The results indicated that shade species affected the cocoa production. Teak shade gave higher production of cocoa (i.e 3,01 kg.tree-1)

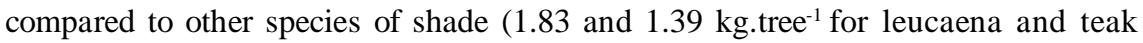
and krete combination, respectively). The correlation of soil quality with cocoa production showed that soil calcium content, earthworm biomass and soil bulk density were positively correlated with the production of cocoa. Shade species greatly affected the production in combination with the soil quality.
\end{abstract}

Keyword: Cocoa, soil quality, shade species, production

\section{INTRODUCTION}

Cocoa (Theobroma cacao L.) is one of the agricultural commodities that is important for Indonesia. Among the agricultural export commodities, cocoa is a third biggest national revenue after oilpalm and rubber. According to International Cocoa Organization (ICCO), the world demand of cocoa increase as much as $2-4 \%$ per year (ICCO, 2009). In the last five year, Indonesian cocoa production is declining. The cause of the declined production of Indonesian cocoa were trees aging, pests and diseases attack, climate change, and soil quality degradation (Wahyudi, 2015).
The soil quality degradation affects cocoa productivity. It will be faster when the soil management was not fulfill the standard of good agricultural practice (GAP). Cocoa productivity is affected by environment and crop management (Liyanda et al., 2013).

Shade reduces and stabilizes soil and air temperature; increases and preserves surface soil humidity and also reduces the direct light intensity reaching the canopy of crops which has a principal role towards amplified production (Alemu, 2015). Cocoa need shade for its best growth (shade loving tree) (Sugito, 2009), however, it still needs 
a certain light intensity for its growth and development. Young cocoa need 25-30\% of full sunlight for its best growth, but mature cocoa need $70-75 \%$ of full sunlight for its highest yield (Abdoellah \& Soedarsono, 1996).

Management of cocoa crops depends on soil. Good soil management gives a better soil fertility and quality. Good soil quality affects cocoa yield and bean quality. There is a positive relationship between physical properties of soil, i.e. permeability, total pores, drainage pores, and bulk density, to the growth and development of crops (Landon, 1984). The better the physical properties of soil, the better the growth and yield of crop, which is due to good soil physical properties, soil nutrients are easier to be absorbed by root plants. Soil nutrients come from organic matter decomposition or from fertilizers. Organic matter in cocoa plantation mostly comes from litter of cocoa and shade trees and manure. Each shade species gives different kind and content of nutrients in their litter. Hence, choosing shade species is very important to get amount of organic litter as well as nutrients from their decomposition. Syaf (2014) found that there was a relationship between soil chemical properties, i.e. $\mathrm{pH}$ $\left(\mathrm{H}_{2} \mathrm{O}\right)$, organic-C and $\mathrm{P}_{2} \mathrm{O}_{5}$ content, to the crop yield. Moreover, the difference of litter quality in agroforestry system of cocoa affects the diversity of soil functioned fauna (Moco et al., 2010). Soil $\mathrm{pH}$, nutrients, and permeability affect the amount and variability of soil fauna.

Cocoa and its shade trees would interact each other. The choice of shade species was very important to get the best interaction. Usually cocoa shade species was legume family, but alternatively using wood as well as fruit trees was a choice to get more income for farmers. A research about using of inga as shade for cocoa got results that cocoa and inga seem to efficiently capture nutrients released from the litter layer on the soil surface, and nutrient leaching in shaded cocoa plantations is unlikely. The proximity of root systems may facilitate $\mathrm{N}$ exchange between the N2-fixing inga (Inga edulis) and cocoa, but competition for other nutrients is likely (Nygren et al., 2013).

This research was done by observing properties of soil physics, soil chemistry, and soil biology as well as cocoa production under three different species of shade, i.e. Leucaena (Leucaena sp), teak (Tectona grandis), and combination of teak and krete (Cassia surithensis). Leucaena and krete are leguminous trees which can symbiosis with nitrogen fixing bacteria, whereas teak is a wood tree that have a secondary function as wind breaker. The aim of this research was to evaluate the role of shade species to the quality of physical-, chemical-, and biological properties of soil, and to investigate their impact on cocoa production grown underneath.

\section{MATERIALS AND METHODS}

This research was carried out for eight months, from October 2016 to June 2017, at Kaliwining Experimental Station and Soil Laboratory of Indonesian Coffee and Cocoa Research Institute (ICCRI), and at the Soil Laboratory of the Soil Department, Faculty of Agriculture, Brawijaya University. Cocoa clones at the trial plots were Sulawesi 1 and Sulawesi 2, 10 years old, and arranged in $3 \mathrm{~m}$ x $3 \mathrm{~m}$ spacing. Research was done by observing soil physical-, chemical-, and biological properties as well as yield. Observation was conducted on three treatments species of shade, i.e. Leucaena sp., teak (Tectona grandis), and combination of teak and krete (Cassia surithensis). Shades were planted in rows between cocoa trees, with the density 125 trees.ha $^{-1}$. Light intensity was observed using light intensity meter under shade, whereas coverage of shade canopy 
was measured by calculating the soil surface area under shade canopy. Measurement of light intensity and coverage of shade canopy were done under 10 sample shade trees per plot those were chosen by sistematic random sampling. Yield data was collected for three months.

The experimental site was defined to three treatments based on the species of shade, i.e. Leucaena, teak, and combination of teak and krete. For each treatment was chosen 40 cocoa trees randomly. Mature and harvested pods were counted every two weeks for three months. In each harvest time 60 pods were taken for pod value and bean count observation. Yield in $\mathrm{kg} /$ tree was calculated based on pod number per sample tree at each harvesting divided by pod value, assumed that the pod value was 30 .

Soil samples were taken by two methods, undisturbed sample for analysis of bulk density and worm population as well as biomass, and disturbed sample for analysis of apparent density (volumetric and gravimetric methods), organic-C (Walkley-Black method), $\mathrm{pH}$ ( $\mathrm{pH}$ meter), $\mathrm{K}, \mathrm{Ca}$ and $\mathrm{Mg}$ (AAS). Soil samples were analyzed at the Soil Laboratory of ICCRI and Brawijaya University.

Data were analysed by analysis of variance. Among treatments were compared using least significant difference (LSD) with $5 \%$ significant level. The relationship between soil quality and yield was tested by regression and correlation tests. All analysis were done using Gen Stat software.

\section{RESULTS AND DISCUSSION}

\section{Soil Physical Properties}

Bulk density and total porosity are two soil physical properties affecting soil quality. The lower the bulk density, the higher the total porosity, and the better the quality of soil. The effect of shade species on bulk density and total porosity of soil are presented in Table 1.

The difference of shade species did not significantly affect the bulk density. Bulk density of topsoil under leucaena, teak and teak and krete were ranged of $0.86-0.95$ g.cm ${ }^{-3}$, whereas bulk density of subsoil were $0.91-$ $0.99 \mathrm{~g} . \mathrm{cm}^{-3}$. The average of topsoil bulk density was lower than subsoil, it meant that topsoil was more porous than subsoil. It was inline to the observation on total porosity, where the average on topsoil was higher than on subsoil. The average topsoil total porosity under various shade species ranged of 58.3$60.2 \%$, whereas the subsoil total porosity was $56.9-59.2 \%$. Topsoil had bulk density lower than subsoil, or it has total porosity higher than subsoil, because it related to the content of organic matter. Mostly topsoil contains higher organic matter than subsoil, that come from litter of vegetation and soil fauna. The abundant of oksigen in topsoil is the factor that affect the higher population of soil fauna than in subsoil.

The typical bulk density ranges of recently cultivated soils was $0.9-1.2$ g. $\mathrm{cm}^{-3}$, surface mineral soils-not recently cultivated but not compacted was 1.1-1.4 g.cm $\mathrm{cm}^{-3}$, and soils showing root restriction was $1.4-1.8{\mathrm{~g} . \mathrm{cm}^{-3}}^{-}$. The total porosity of soils ranged between 30 and $70 \%$ and may be used as general indication of the degree of compaction of soils (Landon, 1984).

\section{Soil Chemical Properties}

One of the function of shade is to supply nutrients on soil through decomposition of its litter. The rate of decomposition is affected by the composition of substances in litter, such as lignin, cellulose, etc. The effect of shade species on soil chemical properties is presented in Table 2 . 
Tabel 1. Effect of shade species on bulk density and total porosity of soils

\begin{tabular}{|c|c|c|c|c|}
\hline \multirow{2}{*}{ Shade species } & \multicolumn{2}{|c|}{ Bulk density $\left(\mathrm{g} \mathrm{cm}^{-3}\right)$} & \multicolumn{2}{|c|}{ Total porosity (\%) } \\
\hline & Topsoil & Subsoil & Topsoil & Subsoil \\
\hline Leucaena & $0.86 \mathrm{a}$ & $0.96 \mathrm{a}$ & $60.19 \mathrm{a}$ & $58.94 \mathrm{a}$ \\
\hline Teak & $0.95 \mathrm{a}$ & $0.99 \mathrm{a}$ & $58.28 \mathrm{a}$ & $56.85 \mathrm{a}$ \\
\hline Teak \& krete & $0.91 \mathrm{a}$ & $0.91 \mathrm{a}$ & $59.65 \mathrm{a}$ & $59.18 \mathrm{a}$ \\
\hline
\end{tabular}

Table 2. The effect of shade species on soil chemical properties

\begin{tabular}{|c|c|c|c|c|c|}
\hline \multirow{2}{*}{ Shade species } & \multirow{2}{*}{$\mathrm{pH}$} & \multirow{2}{*}{$\begin{array}{c}\text { Organic-C } \\
(\%)\end{array}$} & $\mathrm{K}$ & $\mathrm{Ca}$ & $\mathrm{Mg}$ \\
\hline & & & \multicolumn{3}{|c|}{$\left(\right.$ me $\left.100 g^{-1}\right)$} \\
\hline Leucaena & $4.92 \mathrm{a}$ & $2.08 \mathrm{a}$ & $0.87 \mathrm{a}$ & $8.90 \mathrm{a}$ & $2.73 \mathrm{a}$ \\
\hline Teak & $5.55 \mathrm{~b}$ & $2.38 \mathrm{a}$ & $0.76 \mathrm{a}$ & $11.25 \mathrm{~b}$ & $3.86 \mathrm{a}$ \\
\hline Teak \& Krete & $5.42 \mathrm{~b}$ & $2.56 \mathrm{a}$ & $0.69 \mathrm{a}$ & $10.91 \mathrm{~b}$ & $3.13 \mathrm{a}$ \\
\hline
\end{tabular}

Shade species provided significantly difference on soil $\mathrm{pH}$ and calcium. The highest $\mathrm{pH}$ was found in soil under teak shade, whereas the lowest was found under leucaena. These were inline with calcium and magnesium content of soil, although on magnesium was not significant. Calcium and magnesium are lime substances, which may increase soil $\mathrm{pH}$. The highest $\mathrm{pH}$ as well as $\mathrm{Ca}$ and $\mathrm{Mg}$ content was found on soil under teak, with the values were $5.55 ; 11.25$ me

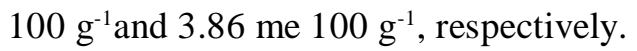

Shade species was not significantly affect the content of soil organic carbon and potassium. The range of soil organic carbon as well as potassium content under various shade species were $2.08-2.56 \%$ and $0.69-$

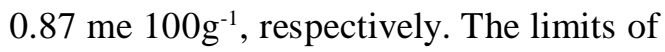
adequacy of potassium, calcium, and magnesium content in soil for cocoa cultivation were $0.24 ; 8.0$; and 2.0 ; respectively, whereas the optimum range of $\mathrm{pH}$ was 6.0 7.5 and minimum organic carbon was $2.0 \%$ (Wood \& Lass, 1985).

According to the rating of $\mathrm{pH}$, soil under leucaena and teak combined with krete shades had low class, whereas soil under teak was medium class. Soil under all shade species had low rating of organic carbon.
Teak and teak combined with krete shades gave medium rating of potassium content of soils, whereas leucaena gave high value. Calcium and magnesium content under all shade species had high rating (Landon, 1984).

\section{Soil Biological Properties}

The presence of earthworm is frequently used as an indicator of good biological property of soils. Shade gives a suitable condition for earthworm habitat through its protection from direct sunlight as well as through vegetation litters. The effect of shade species on population and biomass of earthworm is presented on Table 3.

Soil under leucaena contained the highest population and biomass of earthworms, whereas soil under teak was the lowest. Leucaena have leaves with small size, evergreen throughout the year, so it transmit diffuse sunlight to the soil surface throughout the year. The fallen leucaena leaves on the ground were ready to be feed for earthworms. It gives an optimum condition as habitat of earthworms. The feed of earthworm was plant litter, cattle manure, or death soil fauna (Febrita et al., 2016). It was contrary with teak leaves. The size of teak leaf was 
Table 3. The effect of shade species on population and biomass of earthworm

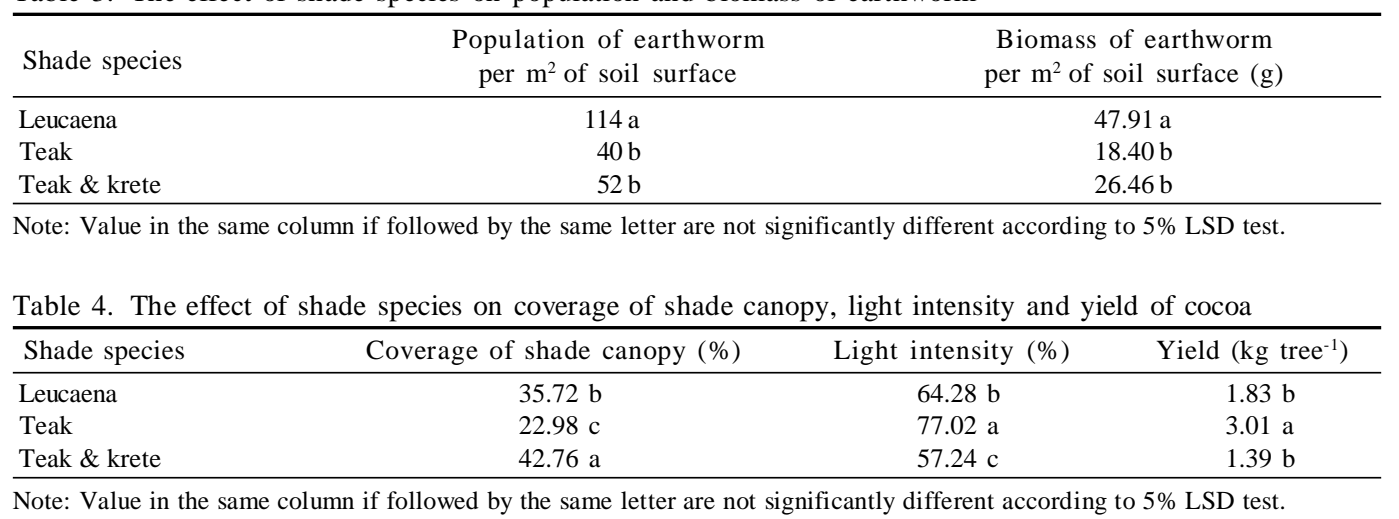

wider than leucaena, and in dry season was fallen, so it was not protect soil surface from direct sunlight. The fallen teak leaves was hard and not ready to be a feed for earthworms. On the other hand, krete leaf has character in between leucaena and teak, so its effects on earthworm population and biomass were also in between leucaena and teak.

Earthworm prefers moist soil, good aeration, warm temperature around $21^{\circ} \mathrm{C}$, $\mathrm{pH}$ 5.0-8.4; high content of organic matter, and low salinity. The shallow level of ground water and coarse texture was not suitable for earthworm (Firmansyah et al., 2014). Earthworm activities improves soil biopore and increasing the amount of vertical and horizontal pores (Amirat et al., 2014).

\section{Cocoa Yield}

One of the function of shade is to reduce sunlight intensity that reach cocoa canopy which can affect the yield. Unsuitable light intensity will lower yield. The effect of shade species on coverage of shade canopy, light intensity and yield as shown in Table 4 .

Teak significantly gave the lowest coverage of canopy, whereas teak with krete was the highest. It was significantly opposite with light intensity, where teak gave the highest and teak with krete was the lowest.
Hence, krete canopy was too dense so it significantly increase the coverage but reduce the intensity of sunlight that reach soil surface. Observation on yield showed that teak significantly gave the highest than other shades, i.e. $3 \mathrm{~kg} \cdot \mathrm{tree}^{-1}$. If that yield was related to the coverage of shade canopy and light intensity showed that the highest yield was reached at the value of shade canopy cover of $23.0 \%$ or light intensity of $77.0 \%$. Most experiment recommend the optimum light intensity to reach the highest yield was around 75\% (Abdoellah \& Soedarsono, 1996). In Ghana, recommended shade canopy cover was 3040\% (Asare, 2013). Shade species affects leaf area index, stomatal density, leaf chlorophyll content, leaf nitrogen content, and specific leaf area of cocoa underneath (Regazzoni et al., 2014). However, the other research showed that shade trees system for cocoa by cocoa-legume and cocoa-timber resulted in similar cocoa yields (Sommariba, 2011).

\section{Soil Properties and Yield Relationship}

Regression and correlation test between soil physical properties and yield of cocoa showed that there is a positive linear relationship between soil bulk density with cocoa yield $\left(\mathrm{R}^{2}=0.09\right)$ (Figure 1$)$. The relationship between soil total porosity to yield has low cofficient of determination $\left(\mathrm{R}^{2}\right)$. This 
suggests that soil physical properties has low influence on cocoa yield.

Figure 1 shows that the range of bulk density was around $0.70-1.10$ g.cm ${ }^{-3}$. Most earlier research found that the optimum soil bulk density that gave maximum yield for most crops was around 1.00-1.20 g. $\mathrm{cm}^{-3}$. It means that the positive linear relationship between bulk density and yield is not unlimited. When the optimum bulk density have already reached, the next higher bulk density would cause declining yield.

Among all parameters of soil chemical properties those correlated to yield, calcium has highest coefficient of determination. Soil calcium has positive linier regression to yield, with coefficient of determination was 0.15 (Figure 2).

Figure 2 shows that from soil calcium

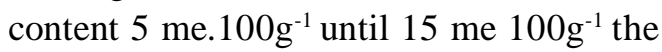
graph is positively linear. It means that the yield would increase with increasing soil calcium up to 15 me. $100 \mathrm{~g}^{-1}$.
Earthworm biomass was positively linear related to cocoa yield $\left(R^{2}=0.17\right)$, whereas the coefficient of determination of earthworm population was low. The higher earthworm biomas means that macropores of soil was abundant, so the soil has good structured. Earthworm was also produce excretion (casting) that improve soil structure.

Coverage of shade canopy was negatively linear related to cocoa yield $\left(\mathrm{R}^{2}=\right.$ 0.19 ), in contrast to sunlight intensity that positively linear related to cocoa yield $\left(\mathrm{R}^{2}\right.$ $=0.19)$. From those graph it was shown that the coverage of shade canopy at $20 \%$, or with light intensity at $80 \%$, the yield was around $3 \mathrm{~kg} \cdot$ tree $^{-1}$. That yield could be reached when supported by good soil fertility. If the soil fertility is not good enough, the yield line will turn horizontally and then decline. Most experiment showed that the optimum light intensity that gave maximum yield of cocoa was around $75 \%$ (Abdoellah \& Soedarsono, 1996).

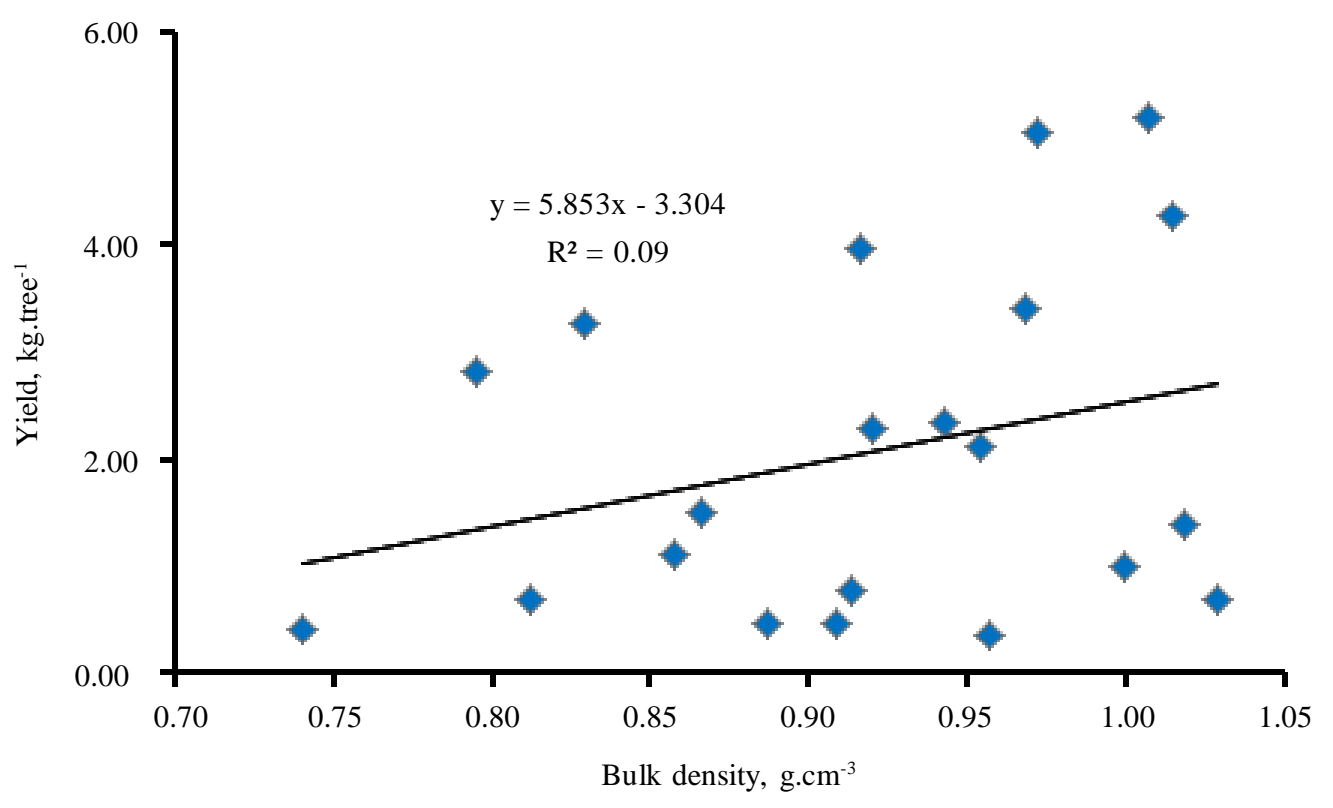

Figure 1. Relationship between soil bulk density with cocoa yield 


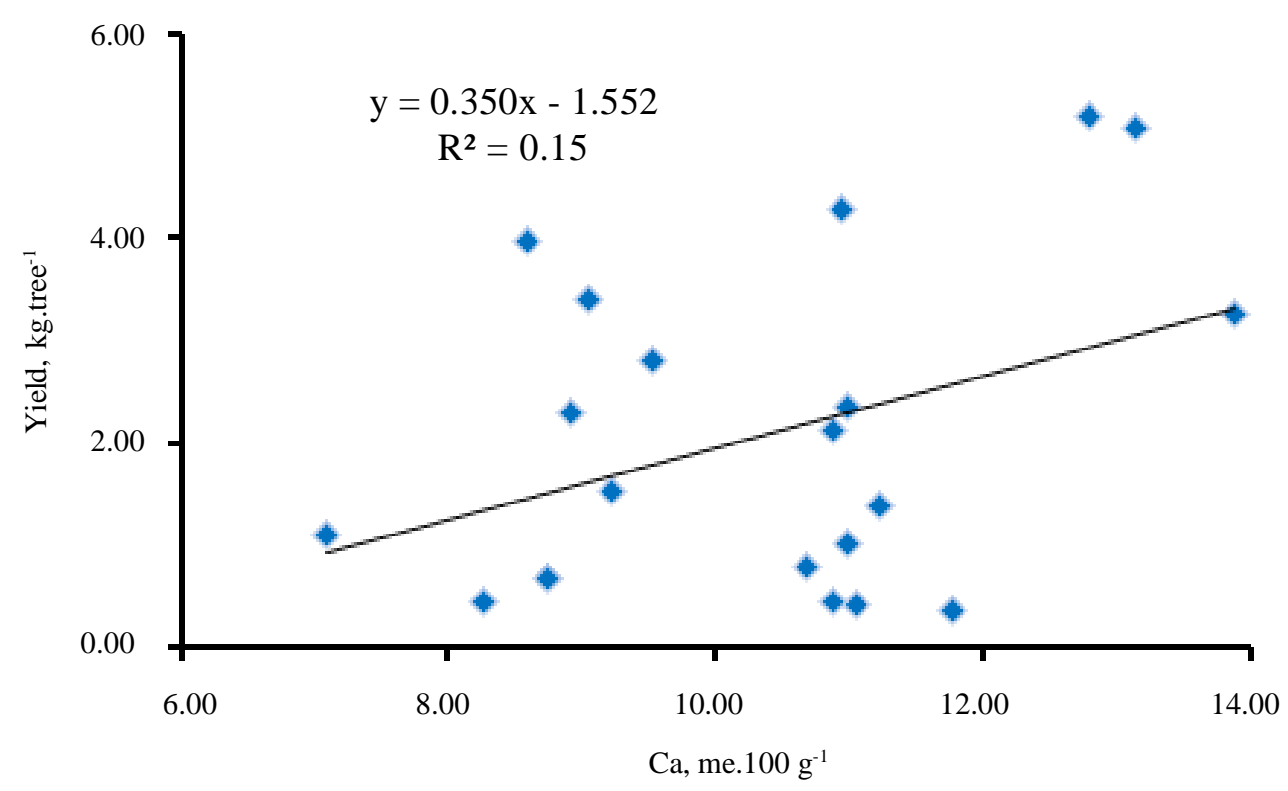

Figure 2. Relationship between soil calcium with cocoa yield

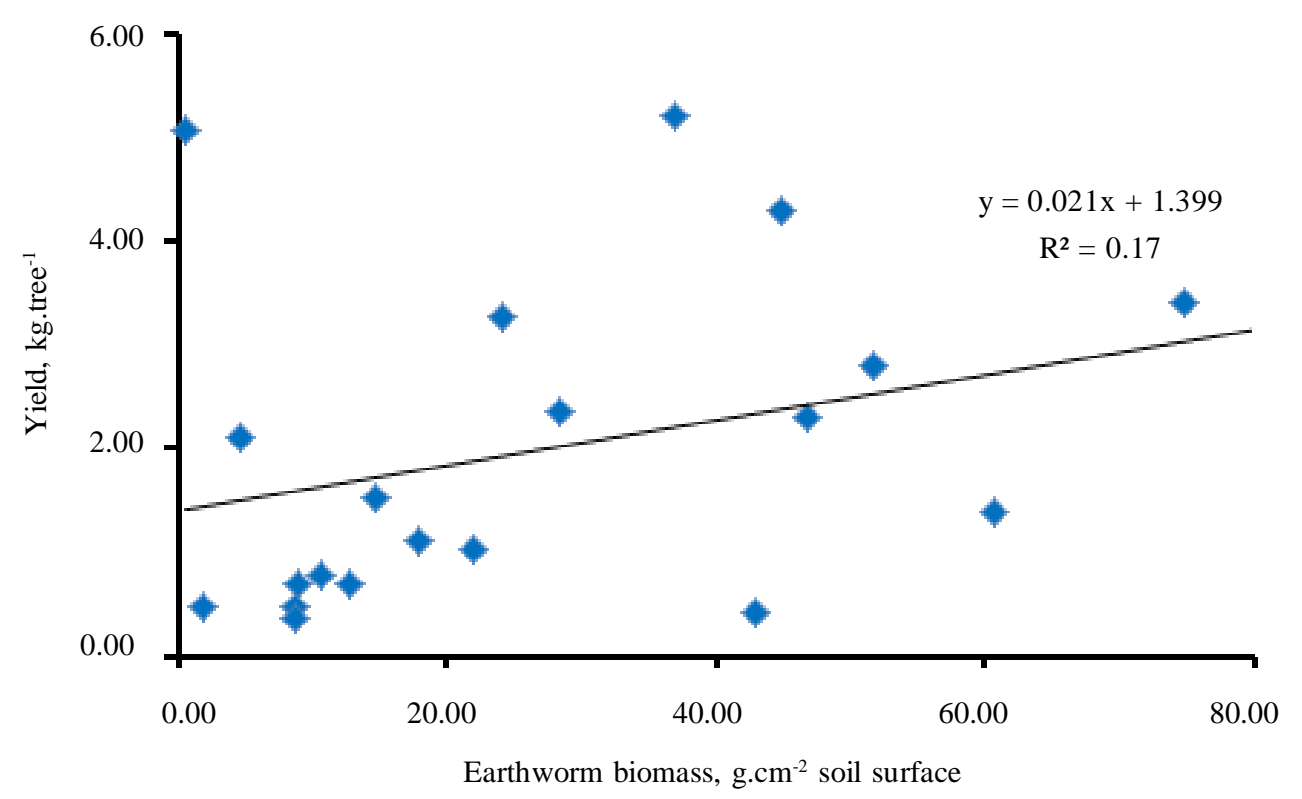

Figure 3. Relationship between earthworm biomass with cocoa yield 
These results was similar with the observation on agroforestry system at Jogjakarta which found that cocoa was well grown under early agroforestry system where the sunlight intensity was more than $50 \%$ (Hani $\&$ Suryanto, 2014). Shade tree canopy gave positive impact on yields depending on the crown area, whereas canopy cover coupled with modest fertilizer use gives the best results (Asare, 2015). In this research, the highest yield of cocoa reached at $20 \% \mathrm{t}$ coverage canopy of shade, whereas Asare et al. (2018) in Ghana reported that the highest one was found at 30 percent.

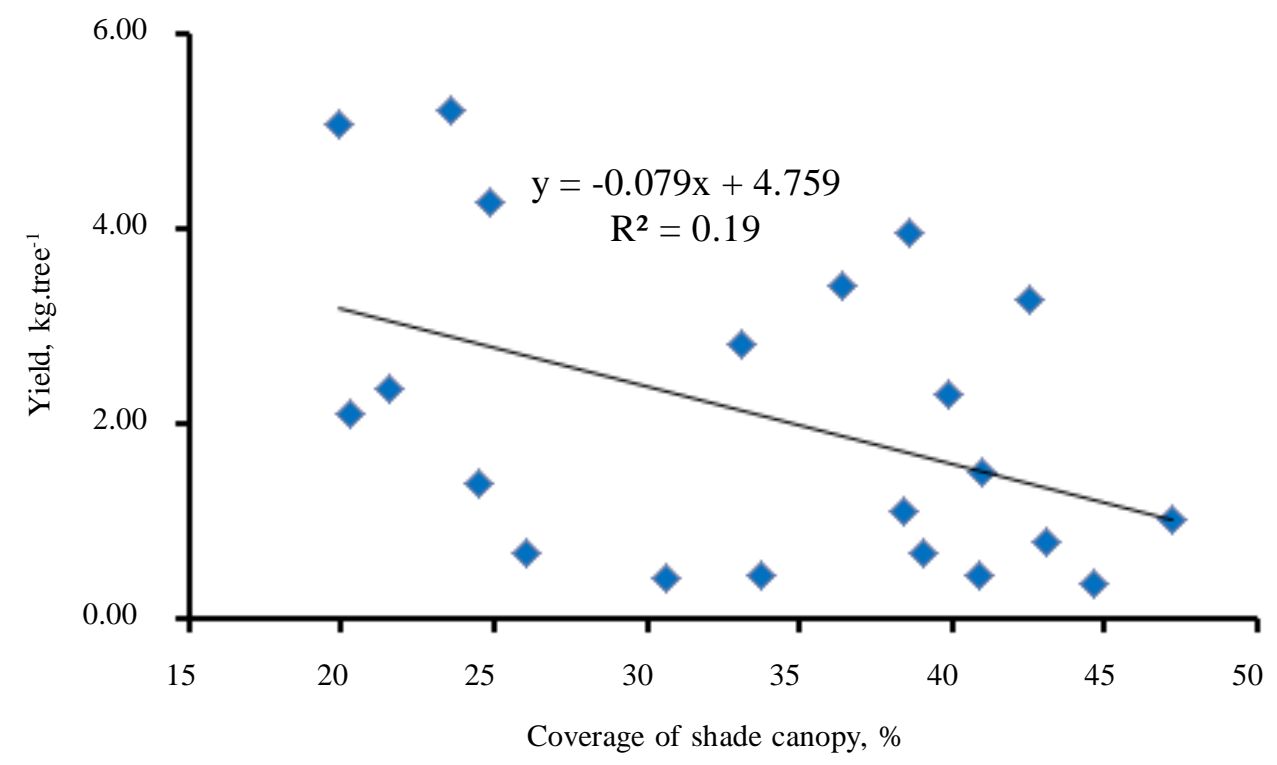

Figure 4. Relationship between coverage of shade canopy with cocoa yield

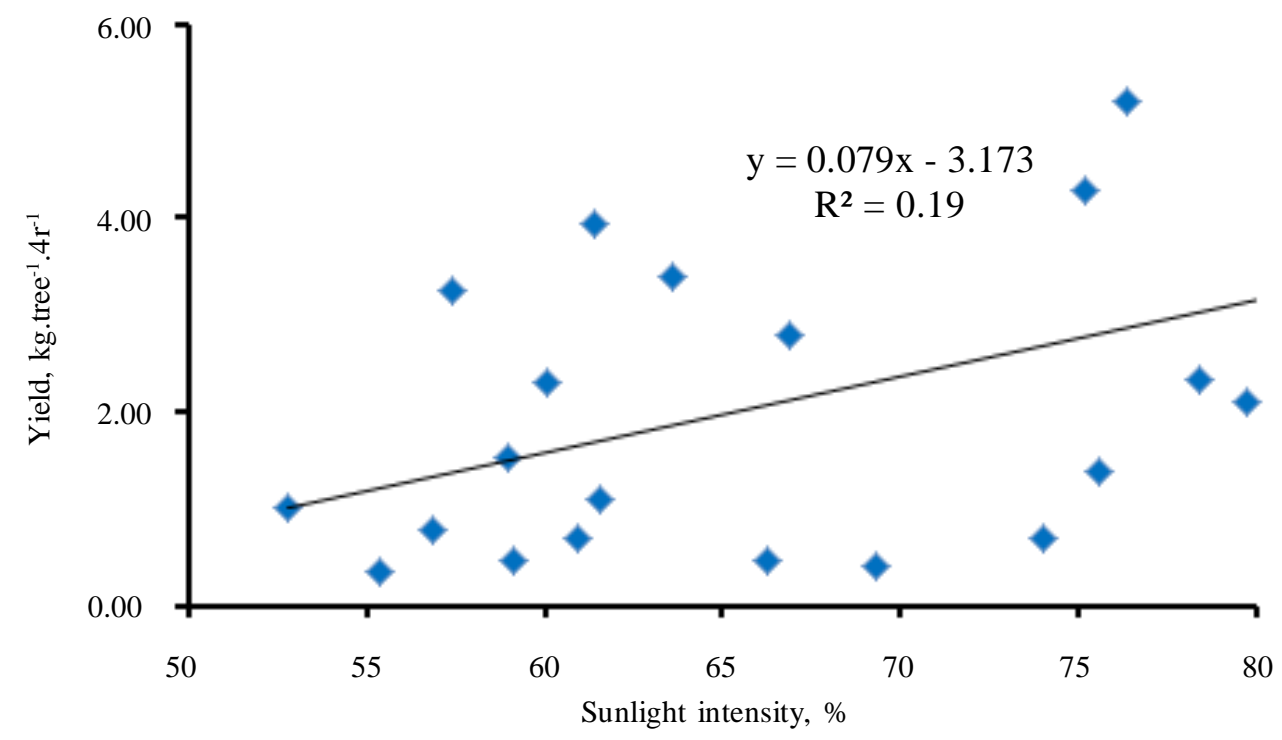

Figure 5. Relationship between sunlight intensity with cocoa yield 


\section{CONCLUSION}

Shade with the canopy coverage of $20 \%$, or equivalent to 80 percent light intensity transmittance gave the highest yield of cocoa underneath. Soil bulk density, soil calcium content, and earthworm biomass were positively correlated with the production of cocoa.

\section{REFERENCES}

Abdoellah, S. \& Soedarsono (1996). Penaung dan pemangkasan kakao, suatu tinjauan dari aspek iklim mikro dan kesuburan tanah. Warta Pusat Penelitian Kopi dan Kakao, 12, 153-160.

Alemu, M.M. (2015). Effect of tree shade on coffee crop production. Journal of Sustainable Development, 8, 66-70.

Amirat, F.; K. Hairiah \& S. Kurniawan (2014). Perbaikan biopori oleh cacing tanah (Pontoscolexcorethrurus). Apakah perbaikan porositas tanah akan meningkatkan pencucian nitrogen? Jurnal Tanah dan Sumberdaya Lahan, 1, 25-34.

Asare, R.A. (2013). Understanding and Defining Climate-Smart Cocoa: Extension, Input, Yield, and Farming Practices. Forest Trends \& Nature Conservation Research Centre, Accra, Ghana.

Asare, R. (2015). The Relationships Between On-farm Shade Trees and Cocoa Yields in Ghana. PhD Thesis. Department of Geosciences and Natural Resource Management, University of Copenhagen, Frederiksberg.

Asare, R.; B. Markussenc; R.A. Asare; G. AnimKwapong \& A. Ræbild (2018). On-farm cocoa yields increase with canopy cover of shade trees in two agro-ecological zones in Ghana. Climate and Development.

Danial, D.; Y. Fiana; F. Handayani \& M. Hidayanto (2015). Peningkatan produksi dan mutu kakao melalui kegiatan GERNAS di Kalimantan Timur. Prosiding Seminar
Nasional Masyarakat Biodiveritas Indonesia, 1, 1203-1210.

Febrita, E.; Darmadi \& E. Siswanto (2016). Pertumbuhan cacing tanah (Lumbricus rubellus) dengan pemberian pakan buatan untuk mendukung proses pembelajaran pada konsep pertumbuhan dan perkembangan invertebrata. Jurnal Biogenesis, 11, 169-176.

Firmansyah, M.A.; Suparman; Harmini; I.G.P. Wigena \& Subowo (2014). Karakterisasi populasi dan potensi cacing tanah untuk pakan ternak dari tepi Sungai Kahayan dan Barito. Berita Biologi, 13, 333-341.

Hani, A. \& P. Suryanto (2014). Dinamika agroforestry tegalan di perbukitan Menoreh, Kulon Progo, Daerah Istimewa Yogyakarta. Jurnal Penelitian Kehutanan Wallacea, 3, 119-128.

Landon, J.R. (1984). Booker Tropical Soil Manual; A Handbook for Soil Survey and Agricultural Land Evaluation in the Tropics and Subtropics. Booker Agriculture International Ltd.

Liyanda, M.; Abubakar; Karim \& Y. Abubakar (2013). Analisis kriteria kesesuaian lahan terhadap produksi kakao pada tiga klaster pengembangannya di Kabupaten Pidie. Jurnal Manajemen Sumberdaya Lahan, 2, 270-284.

Moço, M.K.S.; E.F. Gama-Rodriguesa; A.C. GamaRodrigues; R.C.R. Machado \& V.C. Baligar (2010). Relationships between invertebrate communities, litter quality and soil attributes under different cacao agroforestry systems in the south of Bahia, Brazil. Applied Soil Ecology, 46, 347-354.

Nygren, P.; H.A. Leblanc; M. Lu \& C.A.G. Luciano (2013). Distribution of coarse and fine roots of Theobroma cacao and shade tree Inga edulis in a cocoa plantation. Annals of Forest Science, 70, 229-239.

Regazzoni, O.; Y. Sugito; A. Suryanto \& A.A. Prawoto (2014). Karakteristik fisiologi klon-klon kakao (Theobroma cacao, L.) di bawah tiga spesies tanaman penaung. Pelita Perkebunan, 30, 198-207. 
Somarriba, E. \& J. Beer (2011). Productivity of Theobroma cacao agroforestry systems with timber or legume service shade trees. Agroforestry System, 81, 109-121.

Sparks, D.L.; A.L. Page; P.A. Helmke; R.H. Loeppert; P.N. Soltanpour; M.A. Tabatabai; C.T. Johnston \& M.E. Sumner (1996). Methods of Soil Analysis Part 3 Chemical Methods. Soil Science Society of America, Inc. American Society of Agronomy, Inc. Madison, Wisconsin USA.
Syaf, H. (2014) Evaluasi hubungan kualitas lahan, pertumbuhan dan produksi kakao berumur lanjut di Kabupaten Kolaka Timur, Provinsi Sulawesi Utara. Jurnal Bioedukasi, 3, September 2014.

Wahyudi, T.; Pujiyanto \& Misnawi (2015). Kakao: Sejarah, Botani, Proses Produksi, Pengolahan, dan Perdagangan. Gadjah Mada University Press. Yogyakarta.

Wood, G.A.R. \& R.A. Lass (1985). Cocoa. Longman, London \& New York.

$* * 0 * *$ 